\title{
Specific Detection of Clavibacter michiganensis subsp. sepedonicus by Amplification of Three Unique DNA Sequences Isolated by Subtraction Hybridization
}

\author{
Dallice Mills, Brian W. Russell, and Janet Williams Hanus
}

Department of Botany and Plant Pathology, Oregon State University, Cordley Hall 2082, Corvallis 97331-2902.

Accepted for publication 1 May 1997.

\section{ABSTRACT}

Mills, D., Russell, B. W., and Hanus, J. W. 1997. Specific detection of Clavibacter michiganensis subsp. sepedonicus by amplification of three unique DNA sequences isolated by subtraction hybridization. Phytopathology 87:853-861.

Three single-copy, unique DNA fragments, designated Cms50, Cms72, and Cms85, were isolated from strain CS3 of Clavibacter michiganensis subsp. sepedonicus by subtraction hybridization using driver DNA from C. michiganensis subsp. insidiosus, C. michiganensis subsp. michiganensis, and Rhodococcus facians. Radio-labeled probes made of these fragments and used in Southern blot analysis revealed each to be absolutely specific to all North American C. michiganensis subsp. sepedonicus strains tested, including plasmidless and nonmucoid strains. The probes have no homology with genomic DNA from related C. michiganensis subspecies insidiosus, michiganensis, and tessellarius, nor with DNA from 11 addi- tional bacterial species and three unidentified strains, some of which have been previously reported to display cross-reactivity with $C$. michiganensis subsp. sepedonicus-specific antisera. The three fragments shared no homology, and they appeared to be separated from each other by at least $20 \mathrm{kbp}$ in the CS3 genome. Internal primer sets permitted amplification of each fragment by the polymerase chain reaction (PCR) only from $C$. michiganensis subsp. sepedonicus DNA. In a PCR-based sensitivity assay using a primer set that amplifies Cms85, the lowest level of detection of C. michiganensis subsp. sepedonicus was $100 \mathrm{CFU}$ per milliliter when cells were added to potato core fluid. Erroneous results that may arise from PCR artifacts and mutational events are, therefore, minimized by the redundancy of the primer sets, and the products should be verifiable with unique capture probes in sequence-based detection systems.

Additional keywords: genome subtraction, potato bacterial ring rot.
Bacterial ring rot disease of potato, incited by Clavibacter michiganensis subsp. sepedonicus, is a major concern of producers of seed potatoes in the United States and also to countries that import United States seed and tablestock potatoes. The long-standing implementation of a policy of zero tolerance for the presence of this pathogen in seed stock can result in the loss of an entire seed lot in which C. michiganensis subsp. sepedonicus is detected. Diagnosis of bacterial ring rot in seed lots is largely dependent upon the occurrence of disease symptoms (30), but some infected cultivars have differing propensities to express symptoms $(5,16)$ and may be either asymptomatic or exhibit atypical symptomatology (2). Current methods of detection of this pathogen rely primarily upon the use of serological procedures (11-13) including an indirect fluorescent antibody staining assay (IFAS) $(13-16,18)$, an enzymelinked immunosorbent assay (ELISA) $(15,37,40)$, and latex agglutination (44). Verification is also corroborated by the presence of Gram-positive coccobacilli with the Gram stain (17) and a bioassay on an alternate host, eggplant (4).

Accurate identification of $C$. michiganensis subsp. sepedonicus by serological procedures is especially difficult when population levels are below 10,000 CFU per gram of plant tissue or milliliter of plant sap. At this cell density, 100 cells or less would be present in a $10-\mu \mathrm{l}$ sample delivered to a microscope slide or microtiter well, and few cells, if any, would be visualized by IFAS or detected by ELISA, the most frequently used immunodetection methods. A further complication arises when potato samples contain Gram-positive coccobacilli that may morphologically resemble $C$. michiganensis

Corresponding author: D. Mills; E-mail address: millsd@bcc.orst.edu

Publication no. P-1997-0527-01R

(C) 1997 The American Phytopathological Society subsp. sepedonicus or exhibit cross-reactivity by IFAS and ELISA $(10,19)$. Moreover, certain nonmucoid variant cells of $C$. michiganensis subsp. sepedonicus that may occur in various natural populations (2) exhibit antigenic variation and escape serological detection.

A repeated DNA sequence (RS) isolated from either total DNA $(28,33)$ or pCS1, an indigenous cryptic plasmid (34) that may also be integrated into the bacterial chromosome (33), was also used to detect C. michiganensis subsp. sepedonicus. However, the RS is not found in all C. michiganensis subsp. sepedonicus strains (34), and it was found to have homology with eight of 11 strains of $C$. michiganensis subsp. insidious (21), a pathogen of alfalfa. Confusion could, therefore, arise when alfalfa and potatoes are used in crop rotation. Similarly, probes made of other $C$. michiganensis subsp. sepedonicus DNA sequences and DNA sequences amplified by polymerase chain reaction (PCR) primers $(35,38)$ either lacked specificity or failed to detect all isolates. Recently, specific PCR primers were synthesized that anneal to the variable region within the intergenic spacer (ITS) region of the rDNA repeat of $C$. michiganensis subsp. sepedonicus, and a 215-bp sequence was amplified between the 16S and 23S rDNA genes (29). Although the 18-mer primer set differed at only two or three bases with respect to the analogous regions in four related subspecies, a PCR product that had about $95 \%$ homology with the ITS of the other subspecies was amplified only from strains of $C$. michiganensis subsp. sepedonicus. The specificity of these primers for C. michiganensis subsp. sepedonicus DNA is dependent upon maintenance of small differences within the variable region.

We adopted an alternative approach utilizing subtraction hybridization in our quest to develop an absolutely specific, highly sensitive, verifiable, PCR-based method of detection of C. michiganensis subsp. sepedonicus. Although DNA annealing studies (9) indicated that $C$. michiganensis subsp. sepedonicus and members of other Clavibacter subspecies were closely related, the percent- 
age of unrelated DNA suggested that single-copy C. michiganensis subsp. sepedonicus-specific DNA sequences might be identified. Subtraction hybridization was used to enrich DNA sequences that were present in the genome of $C$. michiganensis subsp. sepedonicus, but absent from the pooled genomes of other selected microbes. A similar approach was used to clone species-specific DNA sequences from Erwinia carotovora $(8,43)$ and Pseudomonas solanacearum $(7,39)$.

Here, we report the molecular cloning, nucleotide sequences, and synthesis of PCR primer sets for amplification of three singlecopy C. michiganensis subsp. sepedonicus-specific DNA fragments isolated by this approach. PCR primer sets for amplification of dispersed, single-copy DNA sequences are crucial for development of a sequence-based detection system, such as PCR-ELISA, that utilizes different capture probes to verify results. Moreover, multiple mutational events in the primer sequences would be required to invalidate this approach. PCR detection of this pathogen in potato fluid with one primer set was greater than immunodetection methods and equal to, or more sensitive than, detection with primers that amplify the ITS region.

\section{MATERIALS AND METHODS}

Bacterial strains, plasmids, and growth media. C. michiganensis subsp. sepedonicus strains and other bacteria used in this study (Table 1) were grown at ambient temperature on nutrient broth yeast extract (NBY) (42) and potato dextrose agar amended with $20 \mathrm{~g}$ of $\mathrm{CaCO}_{3}$ /liter. Escherichia coli strains DH5 $\alpha$ (Gibco BRL, Gaithersburg, MD) and INVaF' (Invitrogen Corp., San Diego, CA) were grown at $37^{\circ} \mathrm{C}$ on Luria-Bertani medium and used for maintenance of plasmids and the clone library. Cloning was achieved using pUC vectors (45) and pCR1000 (Invitrogen Corp.), a T/A cloning vector.

IFAS tests were performed by the Plant Clinic at Oregon State University following standard procedures (18). The 9A1 monoclonal antibody (Agdia, Inc., Elkhart, IN) was used in conjunction with fluorescein-tagged goat anti-rabbit serum (Boehringer Mannheim Biochemicals, Indianapolis, IN).

Preparation of target and driver DNA. Total genomic DNA was extracted from all strains using the cetyltrimethylammonium bromide (CTAB) procedure (1). Target DNA was extracted from a 100-ml stationary phase culture of $C$. michiganensis subsp. sepedonicus strain CS3, treated with RNase A $(100 \mu \mathrm{g} / \mathrm{ml})$ (CalBiochem, La Jolla, CA), and concentrated by ethanol precipitation. Approximately $70 \mathrm{mg}$ of DNA was dissolved in $10 \mathrm{ml}$ of Tris-EDTA (TE) buffer (36), frozen at $-70^{\circ} \mathrm{C}$, and passed twice through an Eaton Pressure Cell (5,800 lb/in²) (W. A. Schaerr, Brooklyn, NY) using a Wabash hydraulic press (Wabash Metal Products, Inc., Wabash, IN). Approximately $20 \mathrm{mg}$ of sheared DNA was centrifuged through a

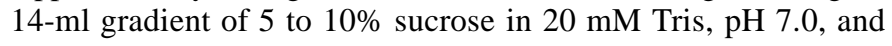

TABLE 1. Clavibacter michiganensis subsp. sepedonicus strains and other bacterial strains analyzed by DNA:DNA hybridization with probes made of Cms50, Cms72, and Cms85, and polymerase chain reaction (PCR) primer sets that amplify these sequences

\begin{tabular}{|c|c|c|c|c|c|c|c|}
\hline \multirow[b]{2}{*}{ Species and strain number ${ }^{\mathrm{a}}$} & \multirow{2}{*}{$\begin{array}{c}\text { Colony } \\
\text { morphology }\end{array}$} & \multirow{2}{*}{$\begin{array}{c}\text { IFAS } \\
\text { reaction }^{\mathrm{c}}\end{array}$} & \multicolumn{3}{|c|}{ DNA:DNA hybridization ${ }^{\mathrm{d}}$} & \multirow{2}{*}{$\begin{array}{c}\text { Detection } \\
\text { by } \text { PCR }^{\mathrm{e}}\end{array}$} & \multirow[b]{2}{*}{ Source $^{\mathrm{f}}$} \\
\hline & & & Cms50 & Cms72 & Cms85 & & \\
\hline \multicolumn{8}{|c|}{ C. michiganensis subsp. sepedonicus } \\
\hline $\mathrm{P} 45$ & Mucoid & + & + & + & + & + & 2,1 \\
\hline $\mathrm{cms} 1$ & Mucoid & + & + & + & + & + & 3 \\
\hline $\mathrm{cms} 3$ & Mucoid & + & + & + & + & + & 3 \\
\hline $\mathrm{cms} 4$ & Mucoid & + & + & + & + & + & 3 \\
\hline $\mathrm{cms} 9$ & Mucoid & + & + & + & + & + & 3 \\
\hline $7706 a$ & Mucoid & + & + & + & + & + & 4 \\
\hline $7706 c$ & Mucoid & + & + & + & + & + & 4 \\
\hline $7706 \mathrm{e}$ & Mucoid & + & + & + & + & + & 4 \\
\hline 8012 & Mucoid & + & + & + & + & + & 4 \\
\hline $8066 b$ & Mucoid & + & + & + & + & + & 4 \\
\hline $8818 \mathrm{a}$ & Mucoid & + & + & + & + & + & 4 \\
\hline $\mathrm{R} 14$ & Intermediate & + & + & + & + & + & 4,1 \\
\hline SD1\#2 & Nonmucoid & + & + & + & + & + & 3 \\
\hline $084-4$ & Intermediate & $\mathrm{ND}^{\mathrm{g}}$ & + & + & + & + & 5 \\
\hline $087-3$ & Nonmucoid & ND & + & + & + & + & 5 \\
\hline $087-10$ & Intermediate & ND & + & + & + & + & 5 \\
\hline $087-15$ & Nonmucoid & ND & + & + & + & + & 5 \\
\hline $087-21$ & Nonmucoid & ND & + & + & + & + & 5 \\
\hline \multirow[t]{2}{*}{$087-24$} & Nonmucoid & ND & + & + & + & + & 5 \\
\hline & & & & & & \multicolumn{2}{|c|}{ (continued on next page } \\
\hline
\end{tabular}

${ }^{\mathrm{a}}$ ATCC $=$ American Type Culture Collection; CDFA = California Department of Food and Agriculture.

${ }^{\mathrm{b}}$ In reference only to $C$. michiganensis subsp. sepedonicus strains.

${ }^{\mathrm{c}}$ Immunofluorescent antibody stain (IFAS) reaction with 9A1 anti-C. michiganensis subsp. sepedonicus monoclonal antibody.

d 32P-labeled probes made of Cms50, Cms72, and Cms85 and hybridized with Southern-blotted, SmaI-digested genomic DNA.

e PCR performed with Cms50, Cms72, and Cms85 internal primer sets unless otherwise noted. $+=$ Detected. $-=$ Not detected.

${ }^{\mathrm{f}}$ First number denotes person from whom the strain was obtained and second number indicates original source of the strain when known: $1=\mathrm{S}$. De Boer, Agriculture Canada Research Station, Vancouver; 2 = M. Romantschuk, University of Helsinki, Helsinki, Finland; 3 = W. Chun, Department of Plant Soil and Entomology, University of Idaho, Moscow; 4 = D. Opgenorth, California Department of Food and Agriculture, Sacramento; 5 = N. Gudmestad, Department of Plant Pathology, North Dakota State University, Fargo; 6 = F. Niepold, Institute fur Pflanzenschutz in Ackerbau und Grulan, Braunschweig, Germany; $7=$ J. Loper, USDA ARS, Horticultural Crops Laboratory, Corvallis, OR; 8 = L. Moore, Department of Botany and Plant Pathology, Oregon State University, Corvallis.

g $\mathrm{ND}=$ Not determined.

h PCR performed only with Cms85 primer set.

${ }^{i}$ PCR performed only with Cms85 and Cms72 primer sets. 
$10 \mathrm{mM}$ EDTA in a Beckman SW40 rotor $\left(15^{\circ} \mathrm{C}, 85,000 \times g\right)($ Beckman Instruments, Inc., Palo Alto, CA). One-milliliter fractions were collected from each centrifuge tube, and $2 \mu \mathrm{l}$ of each fraction was electrophoresed through a $1 \%$ agarose gel to identify fractions that contained DNA with a mean size of approximately 500 bp. Fractions containing DNA of the desired size were pooled, and the DNA was ethanol-precipitated. The ends of the DNA fragments were made blunt by treatment with Mung Bean Exonuclease III and Klenow fragment according to the manufacture's instructions (Gibco BRL), and an EcoRI adapter was ligated to the ends according to instructions provided by the supplier (Promega Corp., Madison, WI).

The driver DNA was isolated from $C$. michiganensis subsp. michiganensis strains DSM60K, DSM31-79, and 3224, Rhodococcus facians strain 3263, and C. michiganensis subsp. insidiosus strain 2900. Following extraction of DNA and RNase A treatment as above, $125 \mu \mathrm{g}$ of DNA from each strain was combined (500 $\mu \mathrm{g}$ total) and digested for periods of 2 to $10 \mathrm{~min}$ with HaeIII $(0.5$ units $/ \mu \mathrm{l})$ to establish conditions that yielded DNA fragments with a mean size of approximately 1,000 bp (range of 200 to 4,000 bp). DNA was extracted with an equal volume of chloroform/ phenol $(1: 1 \mathrm{vol} / \mathrm{vol})$, followed by extraction with an equal volume of chloroform. The DNA was precipitated with ethanol, and the pellet was dissolved in $200 \mu \mathrm{l}$ of distilled water.

Photobiotinylation of driver DNA. Photobiotin acetate (Sigma Chemical Co., St. Louis) was dissolved in distilled water and mixed with driver DNA at a 2:1 ratio (wt/wt; photobiotin acetate/DNA) and irradiated according to instructions provided with the photobiotinylation kit (Gibco BRL). The DNA solution was brought to $\mathrm{pH} 9.0$ with the addition of 10× TE buffer (final concentration of $10 \mathrm{mM}$ Tris and $1 \mathrm{mM}$ EDTA), excess photobiotin acetate was extracted with an equal volume of 2-butanol until the butanol was clear, and the DNA was precipitated with ethanol in the presence of $2.5 \mathrm{M}$ ammonium acetate. The efficiency of biotinylation was determined using the BluGene kit (Gibco BRL).

Subtraction hybridization. Photobiotinylated driver DNA (50 $\mu \mathrm{g})$ and target DNA $(0.7 \mu \mathrm{g})$ were combined, precipitated, and dried; the pellet was dissolved in $20 \mu \mathrm{l}$ of $3 \times$ SSPE hybridization buffer $\left(20 \times \mathrm{SSPE}\right.$ is $3.6 \mathrm{M} \mathrm{NaCl}, 200 \mathrm{mM} \mathrm{NaH}_{2} \mathrm{PO}_{4}$, and $20 \mathrm{mM}$ EDTA, pH 7.4 [36]), 2.5× Denhardt's solution, 0.5\% sodium dodecyl sulfate, and $100 \mu \mathrm{g} / \mathrm{ml}$ of denatured salmon sperm DNA. The DNA was denatured at $100^{\circ} \mathrm{C}$ for $60 \mathrm{~s}$ and reassociated at $68^{\circ} \mathrm{C}$ for $48 \mathrm{~h}$. The solution was cooled to $55^{\circ} \mathrm{C}, 30 \mu \mathrm{l}$ of HEPES stock buffer (10 mM N-2-hydroxyethylpiperazine- $N$-2-ethanesulfonic acid [HEPES] and $1 \mathrm{mM}$ EDTA, pH 7.5) and $10 \mu \mathrm{l}$ of streptavidin $(1 \mu \mathrm{g} / \mathrm{ml})$ were added, and the solution was gently vortexed at room temperature for $10 \mathrm{~min}$. An equal volume of phenol/chloroform $(1: 1 \mathrm{vol} / \mathrm{vol})$ was added, and the tube was vortexed and then centrifuged at $16,000 \times g$ for $10 \mathrm{~min}$. The aqueous layer was removed, the organic phase was reextracted with $50 \mu$ l of HEPES, and the aqueous phases were combined. Ten microliters of strep-

TABLE 1. (continued from preceding page)

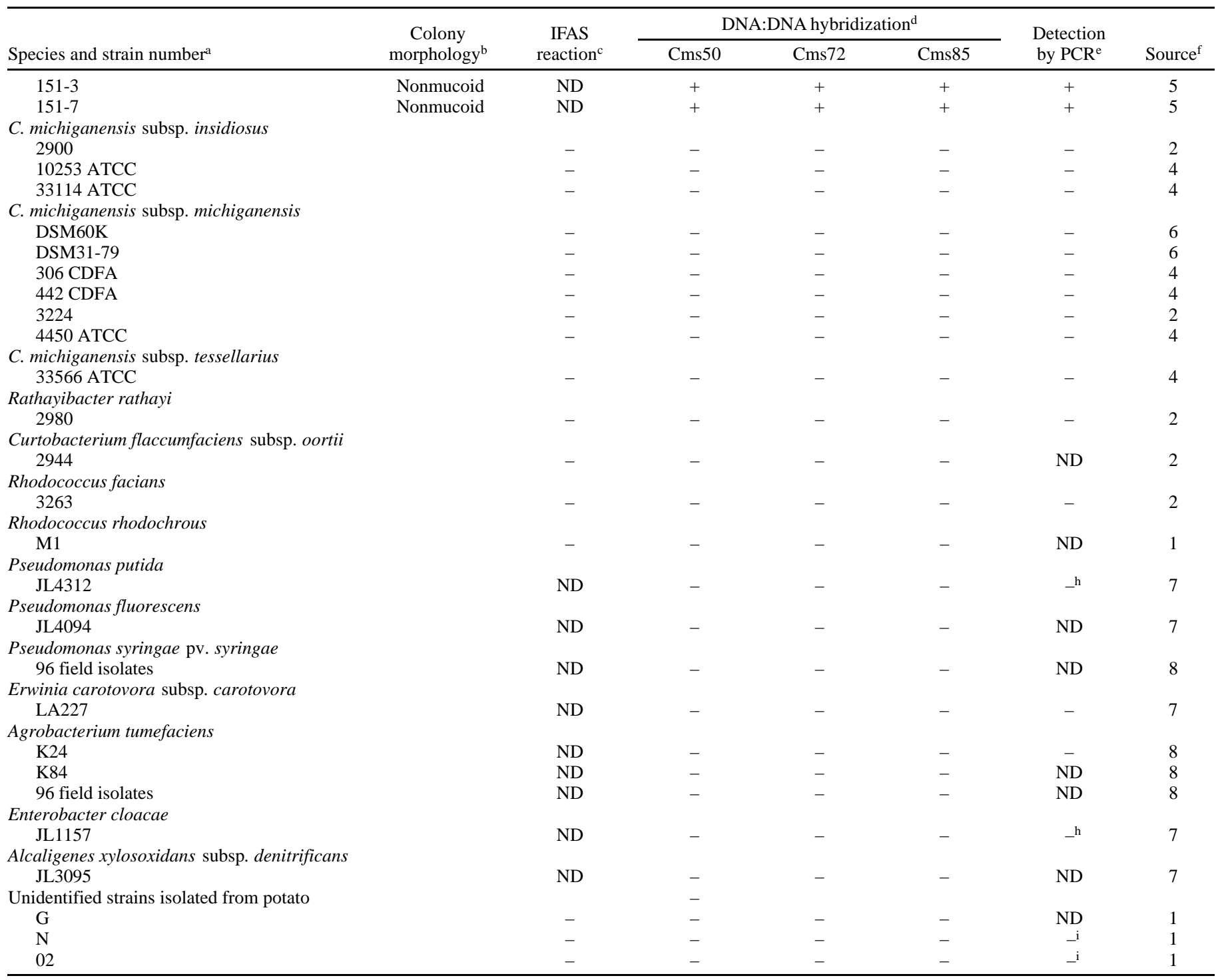


tavidin was added, the mixture was vortexed and extracted with phenol/chloroform, and the DNA was precipitated with ethanol at $-20^{\circ} \mathrm{C}$. This DNA was subjected to two additional rounds of subtraction hybridization, each with the addition of $50 \mu \mathrm{g}$ of driver DNA, as previously described. DNA that remained in solution after the three cycles of subtraction was dissolved in $10 \mu \mathrm{l}$ of distilled water and stored at $4^{\circ} \mathrm{C}$.

Library construction and screening for $C$. michiganensis subsp. sepedonicus-specific DNA fragments and hybridization conditions. For construction of the subtraction library, fragments were amplified from a 16-mer primer (5' AATTCCGTTGCTGTCG $\left.3^{\prime}\right)$ that was complementary to one strand of the EcoRI adapter ligated to the termini of the target fragments. The reaction buffer included $10 \mathrm{ng}$ of target DNA, 15 to 20 pmoles of primer, $200 \mu \mathrm{M}$ dNTPs (United States Biochemical Corp., Cleveland), 1 unit of Taq DNA polymerase, and $1 \times$ PCR buffer (United States Biochemical Corp.) in a 50- $\mu$ l reaction volume. The PCR amplification program was 1 cycle of $60 \mathrm{~s}$ at $96^{\circ} \mathrm{C}, 60 \mathrm{~s}$ at $42^{\circ} \mathrm{C}$, and $2 \mathrm{~min}$ at $72^{\circ} \mathrm{C}$, followed by 25 cycles of $60 \mathrm{~s}$ at $96^{\circ} \mathrm{C}, 30 \mathrm{~s}$ at $50^{\circ} \mathrm{C}$, and $2 \mathrm{~min}$ at $72^{\circ} \mathrm{C}$; the final extension step was $10 \mathrm{~min}$ at $72^{\circ} \mathrm{C}$. Following PCR amplification, the target fragments were cloned into the T/A cloning vector, pCR1000, according to instructions provided by the supplier (Invitrogen Corp.), and the library was maintained in E. coli INVaF'. To screen the library cloned in pCR1000, the plasmids from 200 members were extracted using either the alkaline lysis (36) or a boiling (26) miniprep procedure. The inserts were initially released by digestion with NotI to minimize cutting

\section{DRIVER DNA POOL}

C. m. subsp. michiganensis (DSM60K, 31-79 and 3224);

Rhodococcus facians 3263

C. $m$. subsp. insidiosus 2900

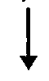

Haell partial digestion

Average size $\sim 1,000 \mathrm{bp}$

Range $~ 200-4,000 \mathrm{bp}$

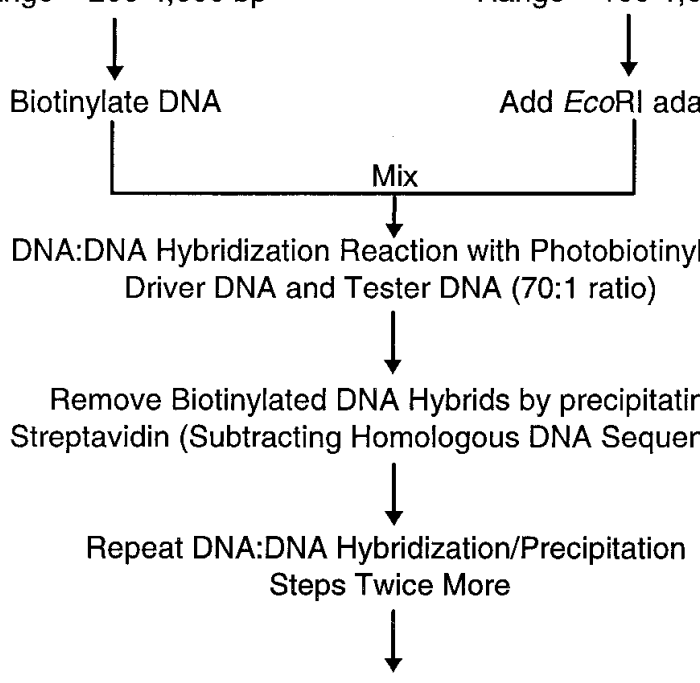

Amplify Enriched C. $m$. subsp. sepedonicus DNA Using one Strand as the Adapter for the PCR Primer

Clone Enriched C. m. subsp. sepedonicus Fragments

Fig. 1. Flow diagram of the method by which Clavibacter michiganensis subsp. sepedonicus-specific DNA was enriched by subtraction hybridization. within the insert, and subsequently with HindIII and EcoRI, which cut within the polylinker leaving 28 and 29 bp of flanking vector DNA. Released inserts and PCR products were separated by gel electrophoresis, purified using QiaexII (Qiagen, Inc., Chatsworth, $\mathrm{CA}$ ), and a radio-labeled probe was made of each with $\alpha\left[{ }^{32} \mathrm{P}\right]-$ dCTP (New England Nuclear, Boston) using the random priming method (22). The genomic DNA extracted from the various bacterial species was quantified using a GeneQuant RNA/DNA calculator (Pharmacia LKB Biotechnology, Piscataway, NJ), digested with SmaI, and an equal concentration of digested DNA was either directly slot-blotted or fractionated by gel electrophoresis and then blotted (41) to a Zeta-Probe GT membrane (Bio-Rad Laboratories, Richmond, CA) using 0.4 M NaOH as the transfer solution. Standard protocols suggested by the manufacturer (Bio-Rad Laboratories) were used for aqueous hybridization and washing the blots. Hybridizations and washes were performed in a hybridization oven at $65^{\circ} \mathrm{C}$.

DNA sequencing, oligonucleotide design, and synthesis. $C$. michiganensis subsp. sepedonicus-specific DNA fragments were sequenced by the Central Services Laboratory, Oregon State University, using an Applied Biosystems model 373 sequencer (Applied Biosystems, Inc., Foster City, CA) and the dye deoxynucleotide termination method (37). These sequences were submitted to the GenBank database under accession numbers AF001266, AF001267, and U96097 for Cms50, Cms72, and Cms85, respectively. Internal PCR primer sets were identified using the Primer Program in the Genetic Computer Group software package (Genetic Computer Group, Inc., Madison, WI), and synthesized by the Central Services Laboratory or by Oligos Etc. (Wilsonville, OR).

PCR conditions for internal primer sets $\mathbf{C m s 5 0 , ~ C m s 7 2 , ~ a n d ~}$ Cms85. DNA was amplified using an Ericomp TwinBlock EasyCycler (Ericomp, Inc., San Diego, CA). Conditions were developed to maximize the amplification of $\mathrm{Cms} 50, \mathrm{Cms} 72$, and $\mathrm{Cms} 85$ from internal primer sets using small quantities of $C$. michiganensis subsp. sepedonicus template DNA. Typically, the conditions were 10 cycles of $45 \mathrm{~s}$ at $94^{\circ} \mathrm{C}, 60 \mathrm{~s}$ at $55^{\circ} \mathrm{C}$, and $10 \mathrm{~s}$ at $72^{\circ} \mathrm{C}$, followed by 40 cycles of $45 \mathrm{~s}$ at $92^{\circ} \mathrm{C}, 40 \mathrm{~s}$ at $55^{\circ} \mathrm{C}$, and $15 \mathrm{~s}$ at $72^{\circ} \mathrm{C}$. The PCR reaction mix consisted of $1 \times T f l$ enzyme buffer (20× supplied by Epicentre Technologies, Madison, WI), $1.5 \mathrm{mM}$ $\mathrm{MgCl}_{2}, 200 \mu \mathrm{M}$ dNTPs, $1 \mu \mathrm{M}$ of each primer, 0.4 units of $T f l$ polymerase (Epicentre Technologies), and 1 to $3 \mu$ of DNA solution in a total reaction volume of $25 \mu$ l. In potato core fluid assays, PCR conditions were identical except that the reaction volume was increased to $50 \mu \mathrm{l}$, the primer annealing temperature was increased to $60^{\circ} \mathrm{C}$, and 2 units of Taq polymerase was used in $1 \times$ Taq buffer A supplied by the manufacturer (Promega Corp.).

Sensitivity of detection of $C$. michiganensis subsp. sepedonicus in potato core fluid by PCR. Using a modified method described by Dinesen and De Boer (20), 100 cores approximately 1 $\mathrm{cm}$ in length were remove from commercially available 'Russet Burbank' potato tubers with a $1-\mathrm{cm}$ cork bore and rinsed briefly in a 250-ml Erlenmeyer flask with sterile distilled water. The flask was decanted, $100 \mathrm{ml}$ of fresh sterile distilled water was added, and the cores were shaken $(300 \mathrm{rpm})$ at room temperature for $3 \mathrm{~h}$. This potato core fluid was used to simulate natural levels of infection when "spiked" with predetermined concentrations of $C$. michiganensis subsp. sepedonicus cells. A culture of $C$. michiganensis subsp. sepedonicus strain CS3 grown in NBY broth medium to an optical density at $600 \mathrm{~nm}\left(\mathrm{OD}_{600}\right)$ of 0.5 (about $10^{8}$ $\mathrm{CFU} / \mathrm{ml}$ ) was serially diluted by 10 -fold increments into water. At each dilution, five replicas of $10 \mu$ were immediately delivered onto solidified NBY medium as described by Bertoni and Mills (3) to determine the number of colony forming units and establish a dilution end point. Twenty microliters of each dilution was also added to $180 \mu \mathrm{l}$ of the potato core fluid and $100 \mu \mathrm{l}$ was immediately frozen; the remainder was treated with InstaGene matrix (Bio-Rad Laboratories) according to the manufacturer's instructions. At each dilution, $10 \mu \mathrm{l}$ of either the frozen or the Insta- 
Gene-treated potato core fluid was then used in a total PCR reaction volume of $50 \mu$ to estimate the sensitivity of detection with the Cms85 primer set. Ten microliters of each PCR reaction was electrophoresed through a $2 \%$ agarose gel and stained with ethidium bromide to determine the minimum colony forming units of $C$. michiganensis subsp. sepedonicus detectable as PCR product.

\section{RESULTS}

Cloning $C$. michiganensis subsp. sepedonicus-specific DNA by subtraction hybridization. The protocol used to enrich $C$. michiganensis subsp. sepedonicus-specific DNA is presented in Figure 1. Target DNA was obtained from CS3, a virulent prototype strain from which anti-C. michiganensis subsp. sepedonicus polyclonal and monoclonal antisera was developed for detection of this pathogen $(10,18)$. The driver DNA was obtained from strains that were either closely related (9) or showed cross-reactivity with anti-C. michiganensis subsp. sepedonicus antisera (10). Following the third round of subtraction, remaining enriched target DNA fragments were amplified using a 16-mer primer complementary to one strand of the EcoRI adapter; the PCR products could be readily visualized in an agarose gel as a smear of DNA fragments corresponding to the expected size range $(<0.1$ to $1.6 \mathrm{~kb}$, data not shown). Because the four-nucleotide overhang of the EcoRI cloning site of the adapter was filled in, the subtraction library was constructed using the T/A cloning vector, pCR1000, which was specifically designed for cloning PCR products. The estimated size of the inserts ranged from approximately 50 to $550 \mathrm{bp}$ among the 200 clones analyzed.

Specificity of clones from the subtraction library. The specificity of the library members was initially determined by Southern hybridization of a ${ }^{32} \mathrm{P}$-labeled probe made of each purified insert to slot blots containing total genomic DNA from $C$. michiganensis subsp. sepedonicus strains CS3 and P45, C. michiganensis subsp. insidiosus (2900), C. michiganensis subsp. michiganensis (DSM60K), Rathayibacter rathayi (2980), Rhodococcus facians (3263), and Curtobacterium flaccumfaciens subsp. oortii (2944) (Table 1). Typically, the probes hybridized with CS3 DNA, but not with DNA from P45 (data not shown). Strain CS3 harbors an indigenous plasmid, pCS1, that is not present in P45 (34). It was expected that numerous clones in the library contained pCS1 sequences that would not have been subtracted by the driver DNA. Many of the inserts also appeared to exhibit either nonspecific binding or have slight homology with DNA from the other species, and these also were not further considered (data not shown). However, inserts, hereafter referred to as $\mathrm{Cms} 50, \mathrm{Cms} 72$, and $\mathrm{Cms} 85$, hybridized specifically with slot-blotted DNA from both CS3 and P45, but showed no homology in the initial screening with DNA from the other strains.

To further examine the specificity of $\mathrm{Cms} 50, \mathrm{Cms} 72$, and Cms85, Southern analyses were performed with blots containing SmaI restriction fragments of total genomic DNA from additional strains of $C$. michiganensis subsp. sepedonicus and a larger collection of other characterized and unknown species (Fig. 2 and Table 1). Each of the labeled inserts exhibited complete specificity for all 29 strains of $C$. michiganensis subsp. sepedonicus, regardless of whether the colony phenotypes were mucoid, intermediate, or nonmucoid (Table 1). The probes did not hybridize with DNA from strains 33114 and 10253 of C. michiganensis subsp. insidiosus, which were previously shown to have homology with a probe made of a RS from pCS1 (21), nor with DNA from seven strains of the related subspecies $C$. michiganensis subsp. michiganensis and $C$. michiganensis subsp. tessellarius. These probes also did not hybridize with DNA from Rathayibacter rathayi, Rhodococcus rhodochrous, and three other unidentified strains that crossreact either with anti-C. michiganensis subsp. sepedonicus polyclonal antisera or monoclonal antibodies $(18,21,22)$. The DNA of seven various plant pathogenic bacteria and soilborne species also did not hybridize with these probes.

Among all $C$. michiganensis subsp. sepedonicus strains, a restriction fragment length polymorphism (RFLP) was detected only in the genome of the nonmucoid strain SD1\#2 when probed with Cms50 and Cms72 (Fig. 2A and B, lane 5). The Southern blot shows a weaker signal with all three probes that was not observed

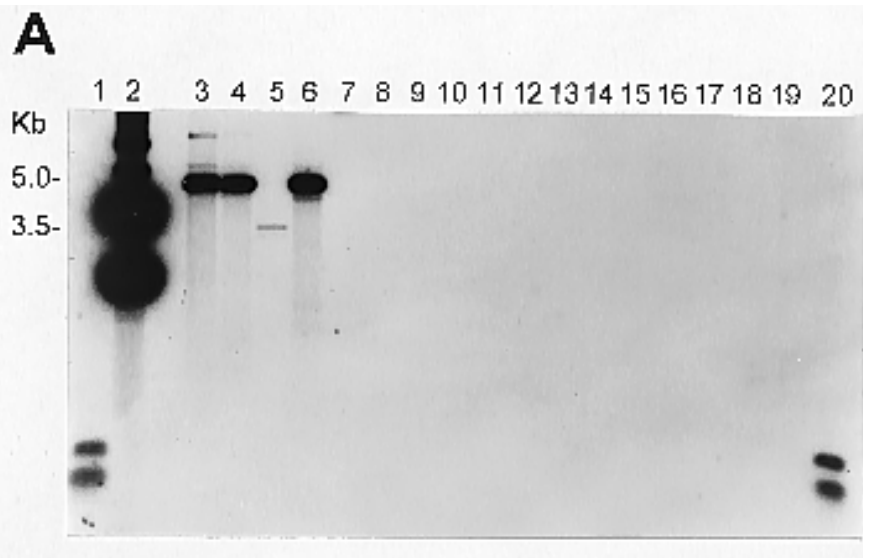

B

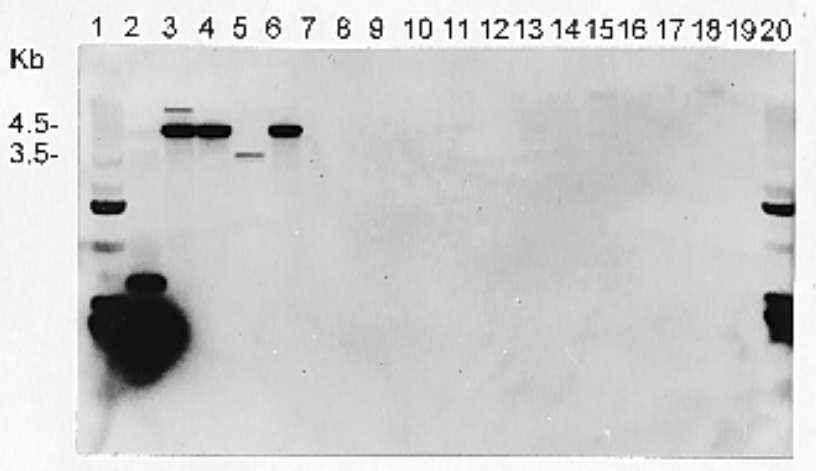

C

1234567891011121314151617181920

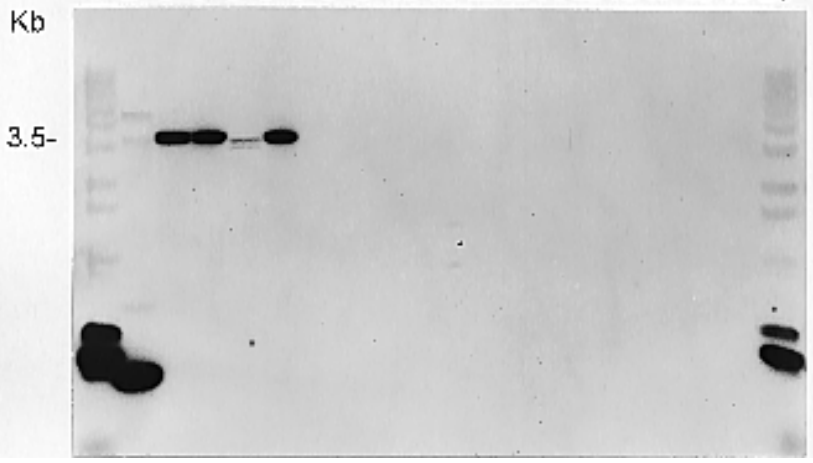

Fig. 2. Autoradiograms of Southern blots containing SmaI-digested genomic DNA hybridized with three Clavibacter michiganensis subsp. sepedonicusspecific DNA probes. The blots were probed with A, Cms50; B, Cms72; and C, Cms85. Lanes 1 and 20, 1-kb ladder (Gibco BRL) showing cross-hybridization to each probe; lane $2, \mathrm{Cms} 72$ insert containing a small segment of the polylinker that has homology with polylinker DNA that also flanks Cms50 and Cms85 sequences; lanes 3 to 6,C. michiganensis subsp. sepedonicus strains P45, CS3, SD1\#2, and Cms3; lane 7, unknown Gram-negative isolate; lanes 8 and 9, C. michiganensis subsp. michiganensis strains 3224 and DSM60K; lane 10, Rhodococcus facians 3263; lane 11, C. michiganensis subsp. insidiosus 2900; lane 12, Rathayibacter rathayi 2980; lane 13, Pseudomonas putida JL4312; lane 14, Pseudomonas fluorescens 4094; lane 15, Erwinia carotovora subsp. carotovora LA227; lanes 16 and 17, Agrobacterium tumefaciens strains $\mathrm{K} 24$ and $\mathrm{K} 84$; lane 18, Enterobacter cloacae JL1157; and lane 19, Alcaligenes xylosoxidans subsp. denitrificans JL3095. 
with DNA prepared from cultures of SD1\#2 derived from single colonies in subsequent experiments (data not shown). The original culture of SD1\#2 was determined to also contain an unidentified Gram-negative bacterium, and DNA from its genome was believed to have contributed to the DNA preparation in lane 5.

Amplification of $C$. michiganensis subsp. sepedonicus-specific DNA. The nucleotide sequences of Cms50 (224 bp), Cms72 (247 bp), and Cms85 (232 bp) are presented in Figure 3. These fragments are not homologous to each other or to other sequences in EMBL and GenBank databanks. Using internal primer sets specific for each fragment (Fig. 3), PCR products of the expected sizes were amplified only from genomic DNA of $C$. michiganensis subsp. sepedonicus, regardless of the colony morphology of the strain (Table 1 and Fig. 4). Moreover, Southern blot analysis with probes made from each fragment hybridized only with the amplicons from C. michiganensis subsp. sepedonicus (Fig. 4). Although DNA sequences from other bacteria were occasionally amplified, the amplicons were of different size, and they had no homology with probes made of $\mathrm{Cms} 50, \mathrm{Cms} 72$, and $\mathrm{Cms} 85$.

Linkage relationships of $\mathrm{Cms50,} \mathrm{Cms72}$, and Cms85. Preliminary linkage relationships of the three fragments were determined by Southern blot analysis of CS3 genomic DNA using single and double digestion with several restriction enzymes (Fig. 5). Radio-labeled probes made of these fragments hybridized with different BglII, HindIII, and EcoRI fragments that ranged in size from approximately $20 \mathrm{~kb}$ to greater than $40 \mathrm{~kb}$, suggesting that they were dispersed rather than closely linked in the genome. A fine structure map of the region of homology with each probe confirmed that these sequences map to different large restriction fragments, and that the three regions of homology in the CS3 genome appear to be separated by at least $20 \mathrm{~kb}$.

Sensitivity of detection in potato extracts. The sensitivity of detection of $C$. michiganensis subsp. sepedonicus was determined by PCR amplification using the Cms85 primer set and a dilution series in water and in potato core fluid (Fig. 6). When $10 \mu \mathrm{l}$ of the PCR reaction was examined by agarose gel electrophoresis, the $10^{-7}$ dilution was the most dilute sample for which the predicted PCR product was visualized for both pure cells and the spiked potato core fluid. At the dilution end point $\left(10^{-7}\right)$, a single colony forming unit was observed in each of five replicas of $10-\mu \mathrm{l}$ ali-

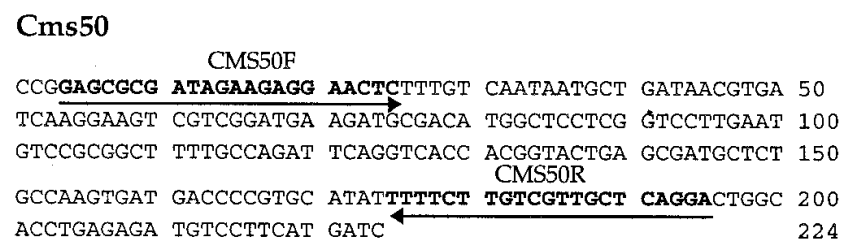

\section{Cms72}

TAGGAACGAA GATGTACTTT CCCTACTTTC GCGGTAAGCA GTTCGAGTTG 50 ATAGCAATCC GCGAGTCAGC GGCGGTCATC GCAGACGCAG GTTTCAATCC 100 GATCATCGAG CCGGTTCGCG AGACCTTCAA AGGACTTCAG CGCACCTTAG 150 CMS72R

ACGAACTGCT CCTGAACGGG GCCAAAGCCA CGGTGATCGT GAATCCGAGA 200 CACGGTGACC ACAGGGATAG CAGCGAAATT CTTGCACAAT ACATGGC 247

\section{Cms85 \\ CMS85F
GAAGATCAGA AGCGACCCGC CATGCTGTCG CACTCTCGAC AGAGAAAGCG 50 AGTCCGCTTT GGCTGTGGAT TCCGGCTCGg TCGTAAGCAG CCTCGAGGTC 100 CTGGGCTTCG GGCTAAGCCA GGTCTTTCCA GGCATCCTGT TCCGTCTGGG 150 CMS85R GTGCGAGCCG ACGAGGATGC GCTGACGGCA TA 232}

Fig. 3. Nucleotide sequences of Clavibacter michiganensis subsp. sepedonicus-specific fragments, Cms50, Cms72, and Cms85. Nucleotides shown in bold print identify the internal forward (right-pointing arrows) and reverse (left-pointing arrows) primers used to amplify each fragment. quots. Microscopic observation of CS3 cells revealed a high frequency of clumped cells, indicating that a colony forming unit may contain two or more cells. Using values obtained for the final three dilutions $\left(10^{-5}\right.$ to $\left.10^{-7}\right)$ to obtain a range for the number of colony forming units at the end point of dilution, we estimated the level of detection corresponded to approximately $100 \mathrm{CFU} / \mathrm{ml}$ (Fig. 6). In other experiments with one unit of Taq polymerase and

\section{0}
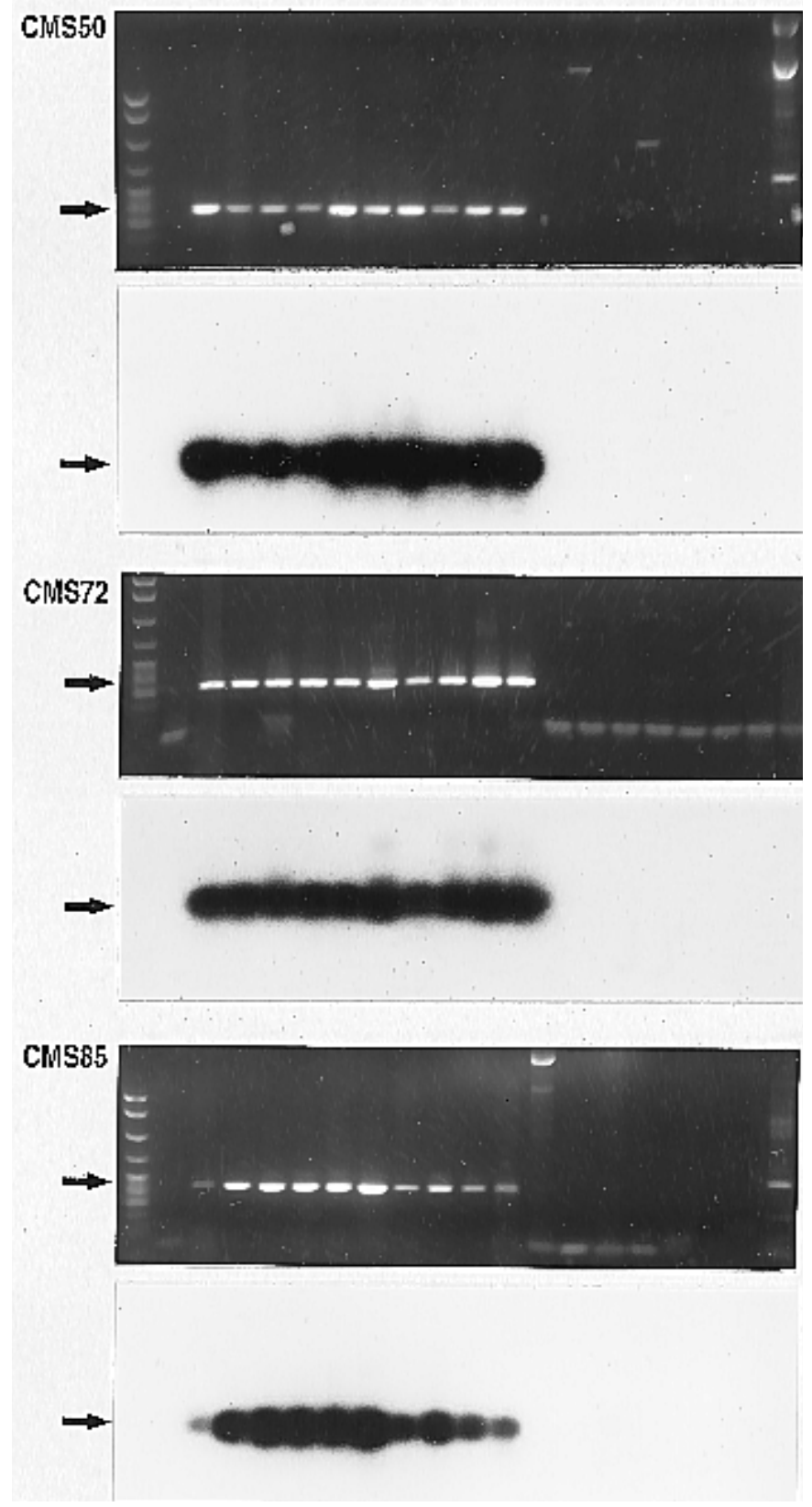

Fig. 4. Polymerase chain reaction (PCR) amplification of Clavibacter michiganensis subsp. sepedonicus DNA from primer sets internal to Cms50, Cms72, and Cms85, and demonstration of specificity by Southern analysis. Ten microliters of PCR product was loaded into each lane, and the arrows indicate the PCR product of expected size for primer sets Cms50 (193 bp), Cms72 (164 bp), and Cms85 (205 bp). The gel in each panel was Southern-blotted and hybridized with a radio-labeled probe made of the appropriate PCR product. In each panel: lane 1, size maker, pBR322 digested with MspI; lane 2, zero DNA negative control; lanes 3 to 12 , C. michiganensis subsp. sepedonicus strains CS3, P45, cms3, 7706e, 7706a, R5, SD1\#2, 084-4, 087-10, and 151-5; lanes 13 to 15, C. michiganensis subsp. michiganensis strains 4450, 442, and 3224; lanes 16 and 17, C. michiganensis subsp. insidiosus strains 33114 and 10253; lane 18, C. michiganensis subsp. tessellarius 33566; lane 19, Rathayibacter rathayi 2980; and lane 20, Rhodococcus facians 3263. The uniform band of less than $50 \mathrm{bp}$ in lanes 2 and 13 to 20 represents primer dimers. 
the primer annealing temperature at $55^{\circ} \mathrm{C}$, the lowest level of detection in spiked potato core fluid was approximately 1,000 $\mathrm{CFU} / \mathrm{ml}$. In contrast, the lowest level of detection of cells diluted in water ranged from 20 to $100 \mathrm{CFU} / \mathrm{ml}$. Potato core fluid spiked with $C$. michiganensis subsp. sepedonicus cells and frozen produced variable PCR results, but highly reproducible results were obtained when replica samples were treated with InstaGene matrix. Cells removed from agar plates and frozen in water required no other treatment to obtain reproducible results. Interestingly, a PCR product of approximately $350 \mathrm{bp}$ was amplified in the potato core sample without added bacteria (negative control) (Fig. 6A, lane 8 ), and again beginning at $10^{-4}$ dilution. This PCR product had no homology with a probe made of $\mathrm{Cms} 85$ (Fig. 6A, lane 8) and was considered to be amplified from an unknown DNA template.

\section{DISCUSSION}

The ability to accurately identify $C$. michiganensis subsp. sepedonicus when present at very low population levels in seed potato tissue is paramount for the production of pathogen-free seed stock, a North American requirement (17). Various immunodetection methods and DNA-based assays are currently used to detect this pathogen. However, all of the assays, except one recently described by $\mathrm{Li}$ and De Boer (29) for amplification of the ITS region of the rDNA, lack complete specificity and the sensitivity required to produce pathogen-free seed stock. The results presented here were obtained with a strategy that incorporated genome subtraction hybridization for cloning random single-copy $C$. michiganensis subsp. sepedonicus-specific DNA fragments. It was not intuitively apparent from which of the closely related strains the driver DNA should be obtained. The DNA from one tester (CS3) and four driver strains, including Clavibacter subspecies that previously were shown by DNA homology to be closely related to $C$. michiganensis subsp. sepedonicus (9), and strains that produce false-positive reactions either with the RS probe or by immunodetection assays (10) were ultimately selected. This strategy proved successful, and DNA sequences designated Cms50, Cms72, and Cms85 were cloned from strain CS3 and verified by Southern blot hybridization to be present only in the genome of $C$. michiganensis subsp. sepedonicus, regardless of colony morphology or plasmid content (Table 1). Moreover, PCR primer sets were synthesized that permitted the specific amplification of each sequence in all $C$. michiganensis subsp. sepedonicus strains examined.
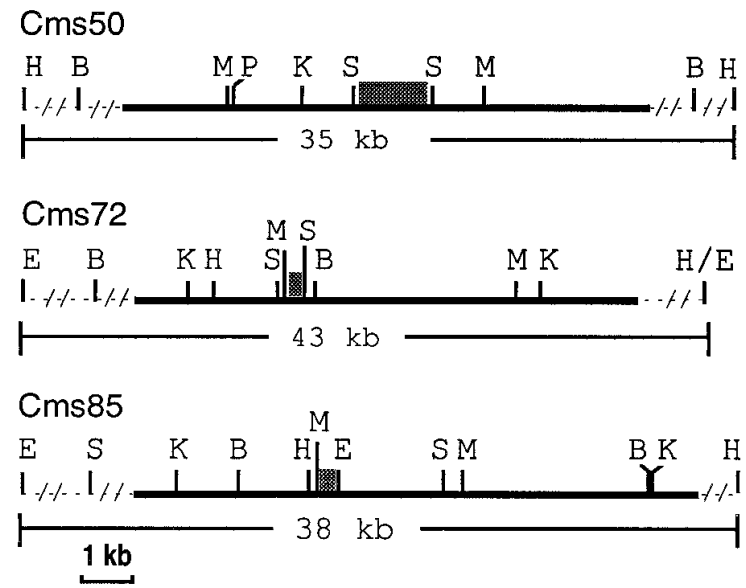

Fig. 5. Linkage relationships of Cms50, Cms72, and Cms85 fragments in the genome of Clavibacter michiganensis subsp. sepedonicus strain CS3. The shaded areas indicate the unique and smallest fragment that hybridized with a probe made of each insert. The 1-kb scale bar relates to genomic DNA as shown by the thick line. DNA identified by dots is not drawn to scale. Letters representing restriction endonucleases: B, BglII; E, EcoRI; H, HindIII; K, KpnI; M, SmaI; P, SpeI; and S, SphI.
Strain CS3, which contains the plasmid pCS1, was selected for tester DNA extraction because antisera produced to this strain has been widely used in detection of $C$. michiganensis subsp. sepedonicus (18). However, selection of the plasmidless strain P45 (34) would have eliminated pCS1 fragments, which appear to have been enriched in the subtraction library and were undesirable for this study. Although Cms50, Cms72, and Cms85 DNA sequences were not present in the driver DNA, it could not be assumed that they would also be absent from the genomes of all other bacteria not

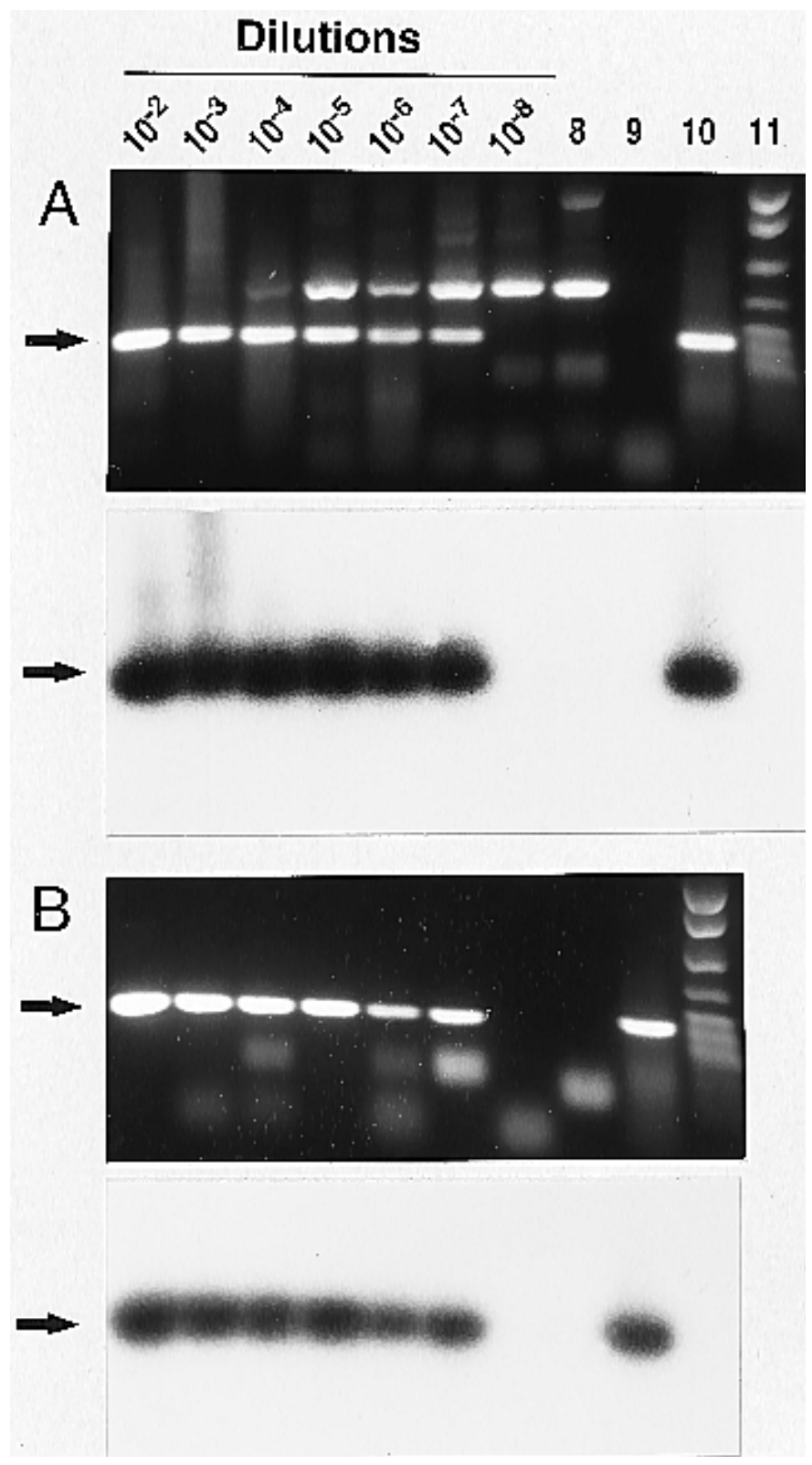

Fig. 6. Sensitivity of detection of Clavibacter michiganensis subsp. sepedonicus by polymerase chain reaction (PCR) amplification with the Cms 85 primer set. The top portion of each panel shows the PCR product amplified at each dilution; the bottom is the respective gel Southern-blotted and hybridized with a probe made of Cms85 PCR product. The arrows indicate the expected 205-bp Cms85 product amplified from the internal primer set. A, Potato core fluid assay. Serial dilutions were made of potato core fluid treated with InstaGene matrix and spiked with CS3 cells. Lane 8, Zero DNA control in potato core fluid; lane 9, zero DNA control; lane 10, positive DNA control (150 pg of strain 7706e); and lane 11, size marker (pBR322 digested with MspI). B, CS3 cells serially diluted into water and treated by freeze/thawing. Lane 8, Zero DNA control; lane 9, positive DNA control (150 pg strain 7706e); and lane 10, size marker (pBR322 digested with $M s p \mathrm{I})$. A $10^{-7}$ dilution in this experiment corresponds to approximately 100 $\mathrm{CFU} / \mathrm{ml}$ for both pure culture and potato core fluid. 
represented in the driver DNA pool. The results of Southern blot analysis (Table 1) clearly indicate that these sequences are specific to $C$. michiganensis subsp. sepedonicus and suggest that this approach may not be restricted to Clavibacter subspecies, but is potentially applicable for isolation of species-specific DNA from any closely related organisms.

Previous reports of specific detection of C. michiganensis subsp. sepedonicus have been based on either nucleic acid hybridization with the RS (21), an oligonucleotide probe targeted to $16 \mathrm{~S}$ ribosomal RNA (32), and probes made of other fragments (28), or by PCR amplification of the RS (40), other sequences from pCS1 (23), and a promoter-like sequence from pCS1 (38). Detection of $C$. michiganensis subsp. sepedonicus by these approaches is of questionable value, because of the lack of specificity. The oligonucleotide probe hybridized specifically with $C$. michiganensis subsp. sepedonicus $16 \mathrm{~S}$ rDNA at $60^{\circ} \mathrm{C}$, but was also shown to hybridize with rRNA from other Clavibacter subspecies at $55^{\circ} \mathrm{C}$ and with all Clavibacter species at $40^{\circ} \mathrm{C}$ (32), indicating that temperature fluctuations could lead to an increased number of false positives. Neither the RS nor the promoter-like sequence from pCS1 is present in the plasmidless strain P45 $(34,38)$, and the RS is present in some strains of $C$. michiganensis subsp. insidiosus (21). Taking advantage of the limited sequence variability within the ITS of the rDNA genes, Li and De Boer (29) designed PCR primers to amplify only $C$. michiganensis subsp. sepedonicus DNA. The PCR primers differ at only two or three nucleotides from sequences present in the ITS of four closely related subspecies, and this small difference may require rigid adherence to the defined annealing temperature to maintain primer specificity. Verification of the specific amplified sequence is only possible if there are restriction sites characteristic for $C$. michiganensis subsp. sepedon$i c u s$, or by obtaining the nucleotide sequence of the PCR product.

The major advantage of a PCR detection procedure based on the amplification of multiple, conserved, single-copy sequences, beyond absolute specificity and high sensitivity, is the opportunity to verify the synthesis of the predicted $C$. michiganensis subsp. sepedonicus-specific PCR products by any sequence detection system (25). Unlike the primers that amplify the ITS, the Cms50, $\mathrm{Cms} 72$, and Cms85 primer sets were constructed from unique sequences and, therefore, temperature fidelity for primer annealing is not as critical to maintain specificity. Moreover, the utilization of the three primer sets either alone or in a single reaction provides the capability of rapidly corroborating results $(6,24,25)$. The three sequences map to different large HindIII, BglII, and EcoRI fragments that appear not to be contiguous in the CS3 genome (Fig. 5), and it appears likely, therefore, that multiple mutations would be required to abolish primer annealing at all three sequences. It was of interest that all three sequences could be amplified in all C. michiganensis subsp. sepedonicus strains, indicating that the primer annealing sequences are highly conserved, but none has apparent homology with any genes in the databanks. It is unclear, therefore, whether a mutation in any of the three sequences would lead to a discernible phenotype or to lethality.

The sensitivity of detection of $C$. michiganensis subsp. sepedonicus in potato extracts by IFAS has been estimated to be approximately 10,000 cells/ml (29). The data presented in Figure 6 indicate that the level of detection of $C$. michiganensis subsp. sepedonicus in potato core fluid with the Cms85 primer set may be as low as $100 \mathrm{CFU} / \mathrm{ml}$, although the range for several experiments was 100 to $1,000 \mathrm{CFU}$. This level of detection appears to be fivefold more sensitive than detection by the specific primers that amplify the multicopy rDNA ITS spacer region (29). The greater sensitivity could merely be a manifestation of the method by which template DNA was prepared and the PCR reaction conditions. The experiments reported here differed in that $C$. michiganensis subsp. sepedonicus template DNA was not extracted per se, which can result in inefficient template recovery. Rather, the DNA was released from freeze/thawed cells in the PCR tubes, presumably during the initial high temperature denaturation treatment, and the spiked potato core fluids were treated with InstaGene matrix to remove components inhibitory to the PCR reaction. Moreover, 10 to 15 more rounds of amplification were performed than were in previous studies $(27,29)$ in the presence of a higher concentration of Taq polymerase, and a lower denaturation temperature was used during the final 40 rounds of amplification to extend the effective specific activity of the enzyme.

The demonstration that probes made of Cms50, Cms72, and Cms85 have absolute specificity for tested $C$. michiganensis subsp. sepedonicus strains from North America, and that a single colony forming unit could be detected in $10 \mu$ of potato fluid by PCR amplification from the $\mathrm{Cms} 85$ primer set, should provide a verifiable approach for detection of this pathogen. In a preliminary study (31; D. Mills and B. W. Russell, unpublished data), the potential to verify the presence or absence of this pathogen by sequence detection was demonstrated. The Cms85 primer set and a complementary capture probe were used in a PCR-ELISA assay, and the PCR product made only from $C$. michiganensis subsp. sepedonicus was detected. PCR amplification of Cms50, Cms72, and Cms85 sequences from low populations, and subsequent verification by a specific capture probe, will greatly enhance the probability of obtaining potato seed stock free of $C$. michiganensis subsp. sepedonicus.

\section{ACKNOWLEDGMENTS}

This research was supported, in part, by USDA-ARS awards 58-3K479-023 and 58-1275-4-022 and the Oregon State University Agricultural Experiment Station, from which this is technical paper 10854. We thank W. Chun, S. De Boer, N. Gudmestad, J. Loper, L. Moore, F. Niepold, D. Opgenorth, and M. Romantschuk for providing strains; M. Putnam and M. Powelson for assistance with immunodetection; and K. Manning for laboratory assistance.

\section{LITERATURE CITED}

1. Ausubel, F. M., Brent, R., Kingston, R. E., Moore, D. D., Seidman, J. G., Smith, J. A., and Struhl, K., eds. 1992. Current Protocols in Molecular Biology. Wiley-Interscience, New York.

2. Baer, D., and Gudmestad, N. C. 1993. Serological detection of nonmucoid strains of Clavibacter michiganensis subsp. sepedonicus in potato. Phytopathology 83:157-163.

3. Bertoni, G., and Mills, D. 1987. A simple method to monitor growth of bacterial populations in leaf tissue. Phytopathology 77:832-835.

4. Bishop, A. L., and Slack, S. A. 1987. Effect of inoculum dose and preparation, strain variation, and plant growth conditions on the eggplant bioassay for bacterial ring rot. Am. Potato J. 64:239-246.

5. Bishop, A. L., and Slack, S. A. 1987. Effect of cultivar, inoculum dose, and strain of Clavibacter michiganense subsp. sepedonicum on symptom development in potatoes. Phytopathology 77:1085-1089.

6. Bourgue, S. N., Valero, J. R., Mercier, J., Lavoie, M. C., and Levesque, R. C. 1993. Multiplex polymerase chain reaction for detection and differentiation of the microbial insecticide Bacillus thuringiensis. Appl. Environ. Microbiol. 59:523-527.

7. Cook, D., and Sequeira, L. 1990. The use of subtractive hybridization to obtain a DNA probe specific for Pseudomonas solanacearum race 3. Mol. Gen. Genet. 227:401-410.

8. Darrasse, A., Kotoujansky, A., and Bertheau, Y. 1994. Isolation by genomic subtraction of DNA probes specific for Erwinia carotovora subsp. atroseptica. Appl. Environ. Microbial. 60:298-306.

9. Davis, M. J. 1986. Taxonomy of plant-pathogenic coryneform bacteria. Annu. Rev. Phytopathol. 24:115-140.

10. De Boer, S. H. 1982. Cross-reaction of Corynebacterium sepedonicum antisera with $C$. insidiosum, $C$. michiganense, and an unidentified coryneform bacterium. Phytopathology 72:1474-1478.

11. De Boer, S. H. 1983 Evaluation of an agar immunodiffusion procedure for confirming bacterial ring rot diagnoses. Am. Potato J. 60:661-669.

12. De Boer, S. H. 1989. Detection of Clavibacter michiganense subsp. sepedonicum in potato. Pages 92-107 in: Detection of Bacteria in Seed and Other Planting Material. A. W. Saettler, N. W. Schaad, and D. A. Roth, eds. The American Phytopathology Society, St. Paul, MN.

13. De Boer, S. H. 1990. Immunofluorescence for bacteria. Pages 295-298 in: Serological Methods for Detection and Identification of Viral and 
Bacterial Plant Pathogens. R. Hampton, E. Ball, and S. De Boer, eds. The American Phytopathological Society, St. Paul, MN.

14. De Boer, S. H., and Hall, J. W. 1988. An automated microscope system for estimating the population of Corynebacterium sepedonicum cells labelled with monoclonal antibodies in immunofluorescence. Can. J. Plant Pathol. 10:215-220.

15. De Boer, S. H., and McCann, M. 1989. Determination of population densities of Corynebacterium sepedonicum in potato stems during the growing season. Phytopathology 79:946-951.

16. De Boer, S. H., and McCann, M. 1990. Detection of Corynebacterium sepedonicum in potato cultivars with different propensities to express ring rot symptoms. Am. Potato J. 67:685-694.

17. De Boer, S. H., and Slack, S. A. 1984. Current status and prospects for detecting and controlling bacterial ring rot of potatoes in North America. Plant Dis. 68:841-844.

18. De Boer, S. H., and Wieczorek, A. 1984. Production of monoclonal antibodies to Corynebacterium sepedonicum. Phytopathology 74:1431-1434.

19. De Boer, S. H., Wieczorek, A., and Kummer, A. 1988. An ELISA test for bacterial ring rot of potato with a new monoclonal antibody. Plant Dis. 72:874-878.

20. Dinesen, I. G., and De Boer, S. H. 1995. Extraction of Clavibacter michiganensis subsp. sepedonicus from composite samples of potato tubers. Am. Potato J. 72:133-142.

21. Drennan, J. L., Westra, A. A. G., Slack, S. A., Delserone, L. M., Collmer, A., Gudmestad, N. C., and Oleson, A. E. 1993. Comparison of a DNA hybridization probe and ELISA for the detection of Clavibacter michiganensis subsp. sepedonicus in field-grown potatoes. Plant Dis. 77:1243-1247.

22. Feinberg, A. P., and Vogelstein, B. 1983. A technique for radiolabelling DNA restriction endonuclease fragments to high specificity activity. Anal. Biochem. 132:6-13.

23. Firrao, G., and Locci, R. 1994. Identification of Clavibacter michiganensis subsp. sepedonicus using the polymerase chain reaction. Can. J. Microbiol. 40:148-151.

24. Fratamico, P. M., Sackitey, S. K., Wiedmann, M., and Yi-Deng, M. 1995. Detection of Escherichia coli 0157:H7 by multiplex PCR. J. Clin. Microbiol. 33:2188-2191.

25. Fujita, S.-I., Lasker, B. A., Lott, T. J., Reiss, E., and Morrison, C. J. 1995. Microtitration plate enzyme immunoassay to detect PCR-amplified DNA from Candida species in blood. J. Clin. Microbiol. 33:962-967.

26. Holmes, D. S., and Quigley, M. 1981. A rapid boiling method for the preparation of bacterial plasmids. Anal. Biochem. 114:193-197.

27. Hu, X., Lai, F.-M., Reddy, S. N., and Ishimaru, C. A. 1995. Quantitative detection of Clavibacter michiganensis subsp. sepedonicus by competitive polymerase chain reaction. Phytopathology 85:1468-1473.

28. Johansen, I. E., Rasmussen, O. F., and Heide, M. 1989. Specific identification of Clavibacter michiganensis subsp. sepedonicum by DNA-hybridization probes. Phytopathology 79:1019-1023.

29. Li, X., and De Boer, S. H. 1995. Selection of polymerase chain reaction primers from an RNA intergenic spacer region for specific detection of Clavibacter michiganensis subsp. sepedonicus. Phytopathology 85:837-842.

30. Manzer, F. E., and Kurowski, C. J. 1992. Bacterial ring rot disease de- velopment in resistant and susceptible cultivars. Am. Potato J. 69:363-370.

31. Mills, D., and Russell, B. W. 1996. Development of a PCR ELISA-based method for specific detection of Clavibacter michiganensis subsp. sepedonicus. (Abstr.) Phytopathology 86:S11.

32. Mirza, M. S., Rademaker, J. L. W., Janse, J. D., and Akkermans, A. D. L. 1993. Specific 16S ribosomal RNA targeted oligonucleotide probe against Clavibacter michiganensis subsp. sepedonicus. Can. J. Microbiol. 39:1029-1034.

33. Mogen, B. D., and Oleson, A. E. 1987. Homology of pCS1 plasmid sequences with chromosomal DNA in Clavibacter michiganensis subsp. sepedonicum: Evidence for the presence of a repeated sequence and plasmid integration. Appl. Environ. Microbiol. 53:2476-2481.

34. Mogen, B. D., Oleson, A. E., Sparks, R. B., Gudmestad, N. C., and Secor, G. A. 1988. Distribution and partial characterization of pCS1, a highly conserved plasmid present in Clavibacter michiganense subsp. sepedonicum. Phytopathology 78:1381-1386.

35. Rademaker, J. L. W., and Janse, J. D. 1994. Detection and identification of Clavibacter michiganensis subsp. sepedonicus and Clavibacter michiganensis subsp. michiganensis by nonradioactive hybridization, polymerase chain reaction, and restriction enzyme analysis. Can. J. Microbiol. 40:1007-1018.

36. Sambrook, J., Fritsch, E. F., and Maniatis, T. 1989. Molecular Cloning: A Laboratory Manual. 2nd ed. Cold Spring Harbor Laboratory, Cold Spring Harbor, New York.

37. Sanger, F., Nicklen, S., and Coulson, A. R. 1977. DNA sequencing with chain-terminating inhibitors. Proc. Natl. Acad. Sci. U.S.A. 74:5463-5467.

38. Schneider, B. J., Zhao, J.-L., and Orser, C. S. 1993. Detection of Clavibacter michiganensis subsp. sepedonicus by DNA amplification. FEMS (Fed. Eur. Microbiol. Soc.) Microbiol. Lett. 109:207-212.

39. Seal, S. E., Jackson, L. A., and Daniels, M. J. 1992. Isolation of a Pseudomonas solanacearum-specific DNA probe by subtraction hybridization and construction of species-specific oligonucleotide primers for sensitive detection by the polymerase chain reaction. Appl. Environ. Microbiol. 58:3751-3758

40. Slack, S. A., Drennan, J. L., Westra, A. A. G., Gudmestad, N. C., and Oleson, A. E. 1996. Comparison of PCR, ELISA, and DNA hybridization for the detection of Clavibacter michiganensis subsp. sepedonicus in field-grown potatoes. Plant Dis. 80:519-524.

41. Southern, E. M. 1975. Detection of specific sequences among DNA fragments separated by gel electrophoresis. J. Mol. Biol. 98:503-517.

42. Vidaver, A. K. 1967. Synthetic and complex media for the rapid detection of fluorescence of phytopathogenic Pseudomonads: Effect of the carbon source. Appl. Microbiol. 15:1523-1524.

43. Ward, L. J., and De Boer, S. H. 1990. A DNA probe specific for serologically diverse strains of Erwinia carotovora. Phytopathology 80: 665-669.

44. Westra, A. A. G., and Slack, S. A. 1994. Comparison of some diagnostic assays for bacterial ring rot of potato: A case study. Am. Potato J. 71: 557-565.

45. Yannisch-Perron, C., Vieira, J., and Messing, J. 1985. Improved M13 phage cloning vectors and host strains: Nucleotide sequences of the M13mp18 and pUC19 vectors. Gene 33:103-119. 